\title{
KNOWLEDGE OF PLACE IN THREE POPULAR MUSIC REPRESENTATIONS OF THE FIRST WORLD WAR
}

\author{
Miha Kozorog \\ Institute of Slovenian Ethnology \\ Research Centre of the Slovenian Academy of Sciences and Arts \\ Department of Ethnology and Cultural Anthropology \\ Faculty of Arts, University of Ljubljana, Slovenia \\ e-mail:miha.kozorog@ff.uni-lj.si
}

\begin{abstract}
This article explores three recent representations of the First World War - specifically of the Isonzo Front - in Slovenian popular music. It considers the works of Rodoljubac, Bakalina, and Bratko Bibič. These musicians and music collectives share a connection to the historical region of the Isonzo Front. The article investigates how these musicians' knowledge of place informed their compositions. Four ways of knowing a place are identified, distributed to varying degrees among the musicians: absorbing locally shared narratives about a place, engagement with landscapes and the environment, personal memories, and analyzing and reconsidering the place. The article contributes to the literature on the involvement of music in the production of place by examining the multitude of ways of knowing a place.
\end{abstract}

Keywords: centennial celebrations, First World War, Isonzo Front, popular music, production of place, Tolmin (Slovenia), (ways of) knowing a place

\section{INTRODUCTION}

This article explores three recent popular music representations of the Isonzo Front, a battlefield from the First World War. ${ }^{1}$ They are works by the following Slovenian musicians and music collectives: Rodoljubac, a garage rock and roll band; Bakalina, a "world music" chanson duo; and Bratko Bibič, an experimental accordion player and composer. In addition to dedicating part of their work to the Isonzo Front, these musicians also share a connection to a particular location in this battlefield. This is the Tolmin area, which has played a role in the musicians' lives, and which also appears to varying degrees in their musical works. 
These relations between place, musicians' lives, and musical representations of place call for an interpretation of music as stimulated by musicians' knowledge of the place, and perhaps their local belonging and/or identification with the place. The article follows this line of argumentation, but also demonstrates that quite different ways of knowing this place have stimulated the musicians to represent it in the context of the war. Different ways of knowing the place have also contributed to differences in knowing its history, and therefore to different portrayals of it.

Anthropological studies of relations between music and place gathered pace in the 1990s together with attention to globalization. This attention stimulated imagining traditional, ethnic, folk, and other musical styles as not place-bound (as they were previously imagined) because every place is always part of a larger world and thus culturally influenced from elsewhere (Connell \& Gibson 2003). At the same time, although music is spatially unbounded, local manifestations of music (of whatever kind) are very much influenced by the local conditions of its production (Cohen 1995; Finnegan 1989; Muršič 2000). Moreover, these conditions are also involved in the production of a particular place. This is the case for several reasons: music is integral to social events; as such, it engenders place-bound memories. Via reproduction, it marks local sound and style. Moreover, musicians, their works, audiences, record labels, events, venues, and so on frequently brand a place. Thus, for example, Sara Cohen (1995) portrayed an inhabitant of Liverpool, who through personal knowledge of the city's musical history reproduces its identity, using musical metaphors.

This article explores a related, yet less frequent inquiry: namely, how different ways of knowing a place stimulate different musical representations of it (which may afterwards function in processes of place production). Hence, although musical production of place has already attracted researchers' attention, involvement of a multitude of ways of knowing a place in this process has remained underexplored. Nevertheless, Steven Feld's classic (1982) on the Kaluli people of Papua New Guinea investigates their knowledge of sounds in the environment as constitutive for local musical language. However, a variety of ways of knowing a place by a set of musicians with different attitudes to place and their translation of this knowledge into music has remained underexplored.

Four ways of knowing a place have contributed to the musical works examined below: absorbing locally shared narratives about the place, engagement with local landscapes and the environment, personal memories, and analyzing and reconsidering the place. These ways of knowing are not exclusive, but are sometimes combined in a musician's experience of place. Nevertheless, they are distributed to varying degrees among the musicians so that in each case one or another stands out more distinctively than others. 
Because popular music representations of the First World War are a very recent phenomenon in Slovenia, it is worth asking how this phenomenon is connected (if at all) with the centennial of the war. The history of Slovenian popular music, as well as folk music, ${ }^{2}$ is very poor in representations of this specific war, and this might therefore suggest that the observed acts of music-making are pragmatic, in the sense that anniversaries can be profitable. For comparative purposes, consider that the Belgian town of Diksmuide commissioned a musical work dedicated to the centennial of the war from the German avant-garde rock band Einstürzende Neubauten. This led to the band's 2014 project Lament which, however, also stimulated a defense of the band's act by frontman Blixa Bargeld: "I have a problem with the avant-garde. Because it's a military term. It means the garde that runs before the rest of the soldiers and if I want to see myself represented in military terms, I don't want to be part of that. I want to be one of the deserters." 3 This comment may make one think that composing and performing for war anniversaries is not an unencumbered task because it is associated with moral ambiguity, possibly endangering a musician's or band's artistic coherence: can one still call Einstürzende Neubauten the "avant-garde" after it was commissioned to compose a piece for a war anniversary? I pay attention to this ambiguity as well. However, there is an important difference between the Diksmuide case and those presented here. Namely, none of the musicians examined here were commissioned by local authorities to compose for the centennial (although some were involved in local centennial programs), but were stimulated in some other way, primarily by their knowledge of the place.

With the cases presented here, I do not wish to reduce music-making to merely a derivative of specific experiencing and knowing of places by musicians. In the production of music, other forces play a considerable role; among these are the musicians' commitment to specific aesthetics, personal expression, and morality, as well as the rules of the musical genre. I take these into account as well.

Below I first present historical, geographical, and ideological frameworks of popular and folk music representations of the Isonzo Front. Then I present the relevant place, in relation to both its heritage and popular music. After this, I present the three musical groups or musicians and their local embeddedness. The conclusion interprets these works with diverse ways of knowing the place. 


\section{POPULAR AND FOLK MUSIC REPRESENTATIONS OF THE ISONZO FRONT: HISTORICAL, GEOGRAPHICAL, AND IDEOLOGICAL CONTEXTS}

The Isonzo Front refers to the battlefields between Austro-Hungary and the Kingdom of Italy, stretching from the Julian Alps to the Adriatic along the Isonzo or Soča River. ${ }^{4}$ During the war, this area was a fierce place, where the two armies found themselves in static combat between 1915 and 1917. In the decades since the First World War, the remnants and memories of the battlefield have been heritagized; however, this has been done to varying degrees by the different countries that inherited these lands. This analysis considers the following countries as contexts for heritagization: the Kingdom of Italy, postwar Italy, the Socialist Federal Republic of Yugoslavia, and independent Slovenia.

After the First World War, the entire area of the Isonzo Front became part of the Kingdom of Italy. Its concern was to carry on the memory of the war to nourish the ideals of heroism of Italian soldiers and citizens as well as to promote the Italian victory. The Italian soldiers were reburied in monumental ossuaries to serve as memorials of the war. In 1938, twenty years after the war, three huge ossuaries commemorating the Isonzo Front were erected and personally inaugurated by the country's leader, Benito Mussolini, who was a soldier on the Isonzo Front before he founded fascism.

A year later another world war started, after which the area of the Isonzo Front was divided between two countries: its western part belonged to Italy, and its eastern part to Yugoslavia. Whereas Italy preserved the memory of the First World War as a heroic era of its history, Yugoslavia instead glorified the Second World War. However, soon after the dissolution of Yugoslavia, when Slovenia became its successor in the Isonzo Front area, the battlefield became actively heritagized. In the 1990s, it was enthusiastically rediscovered and represented by various local protagonists, so that an economically successful and publicly loud heritage industry found its place in the area, particularly in the town of Kobarid.

Popular music and folk music thematizing the First World War in general corresponded to these historical, geographical, and ideological frameworks. Already during the war, songs were composed in the different languages spoken at the battlefields, presumably also for propaganda purposes. For example, on the Italian side of the Isonzo Front there emerged songs in Italian (e.g., "Ho perso la voce sul Podgora" (I Lost My Voice at Podgora), "Monte Nero" (Mount Krn), etc.), but also in Friulan (e.g., "Il furlan" (The Friulian)). ${ }^{5}$ In later periods, these patriotic songs, including those created at the end of the war, such as the popular "La leggenda del Piave" (The Legend of the Piave), co-constructed 


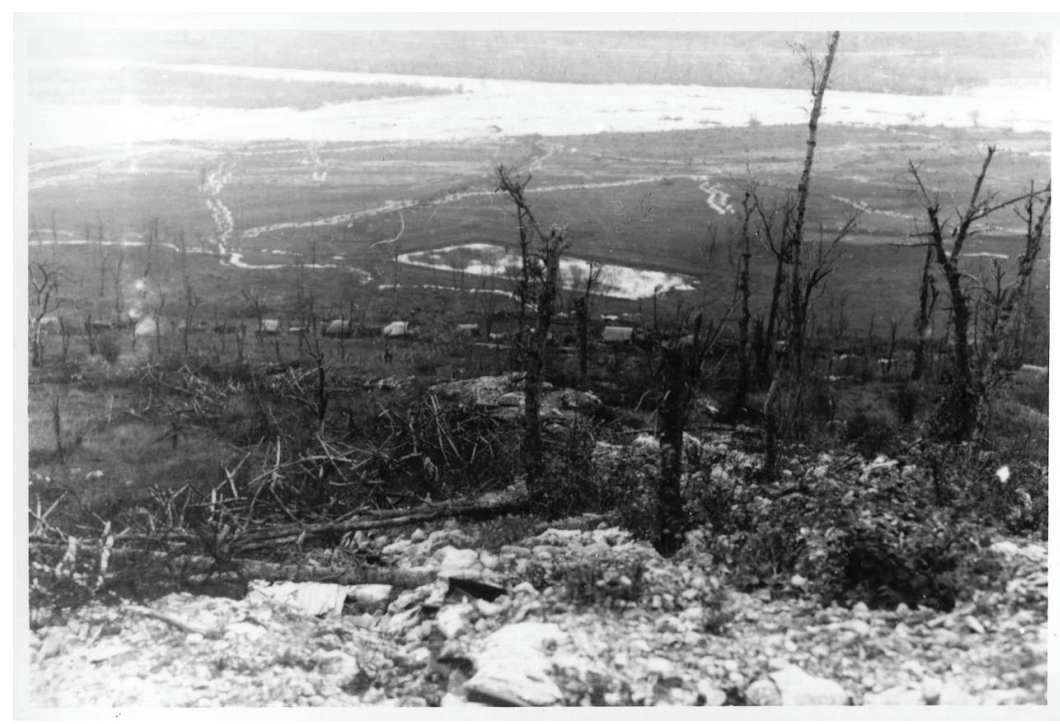

Figure 1. Tolmin valley: a view of the Soča and the abandoned positions of the first front line on the left bank after the successful breakthrough between Tolmin and Bovec. Courtesy of the National Museum of Contemporary History, Slovenia.

the collective memory of Italian citizens, nourishing "the myth of la Grande Guerra" (Pivato 2007: 131).

In the 1960s, however, a widespread "folk revival" countercultural movement emerged in Italy (Carrera 2001), which, following Antonio Gramsci, defined folklore as resistant expression of the subaltern and as narration of an alternative history (Castelli 2009). Ethnomusicologists such as Roberto Leydi publish the journal Nuovo Canzoniere Italiano (New Italian Songbook) to renew public interest in resistance songs. They also use anti-military songs to question the official narrative about the First World War. The clash of values in Italian society could be depicted by one such song, allegedly composed during the war at the Isonzo Front. The song "O Gorizia, tu sei maledetta" (O Gorizia, You Are Cursed) condemns the massacre in the battle for the town of Gorizia, which took place on August 9th and 10th, 1916. The song was written soon after the war, but found its way to the general public only in 1963, when the LP series Canti polotici e sociali (Political and Social Songs), edited by Leydi, released the anti-war collection entitled Il povero soldato (The Poor Soldier; Leydi 1963). However, when Nuovo Canzoniere Italiano received its own space in the program at the Festival dei Due Mondi in Spoleto in 1964, the singing 
of this song by Michele Luciano Straniero (and in particular the verses "traditori signori ufficiali / voi la guerra l'avete voluta / scannatori di carne venduta / questa guerra ci insegni a punir" (And you traitors, generals, officers, / You who strongly pushed for this war, / You're the butchers of our flesh for sale / This war teaches us to smite) provoked screaming in the audience about the glory of Italy. Consequently, Straniero and Leydi were reported to the police for publicly insulting the armed forces. ${ }^{6}$

"O Gorizia, tu sei maledetta" (O Gorizia, You Are Cursed) is a notable example of juxtaposition of an official glorification of the war and an anti-war popular discourse, which opposes both the war and the official discourse on it (Pivato 2007: 139-142). In Yugoslav and Slovenian history, songs from the First World War as well as those about it - not to mention ones with such a destiny as "Gorizia" - are rather absent. This is perhaps largely so because of entirely different political and ideological conditions. Nevertheless, Marija Klobčar, a researcher of Slovenian military folk songs (2007a), analyzed a few such songs from the First World War. She examined and confirmed or reinterpreted previous researchers' claims about these songs (2007b). Namely, Leo Hajek, who recorded the singing of Austro-Hungarian soldiers of various ethnic affiliations in the barracks in Judenburg in 1916 (Klobčar 2007a: 10; 2007b: 49), mentioned melancholy with regard to Slovenians' singing. ${ }^{7}$ According to him, their songs were neither combative nor rebellious (as in the Italian case mentioned above). Another musical phenomenon was observed by Matija Murko, a folk song researcher, in 1916. He mentioned a revival of older, allegedly lost (military) songs, as though special circumstances of crisis stimulated people to broaden their singing repertoire through the revival of older songs (Klobčar 2007b: 39-40). Nonetheless, their use for propaganda purposes should also be considered.

After the Second World War, in Yugoslavia, the songs that remained part of the singing repertoire were not labeled as First World War songs, but were detached from this context. This was largely the case because songs about the partisan movement and antifascist resistance of the Second World War dominated the scene (Hofman \& Pogačar 2017), and so the overall conditions for keeping the repertoire from the previous war alive were not favorable at all. The First World War was outside the scope of inquiry because another war was constitutive for the Yugoslav and Slovenian national consciousness of the time.

In light of these historical, geographical, ideological, and musical contexts, the recent emergence of the First World War as a topic in Slovenian popular music is a phenomenon without historical depth, which calls for an interpretation. As mentioned, an important change occurred with the public reappearance of the First World War in post-Yugoslav Slovenia. However, the musicians 
Figure 2. A group of AustroHungarian soldiers playing in the Tyrolean high mountain battlefield. Courtesy of the National Museum of Contemporary History, Slovenia.
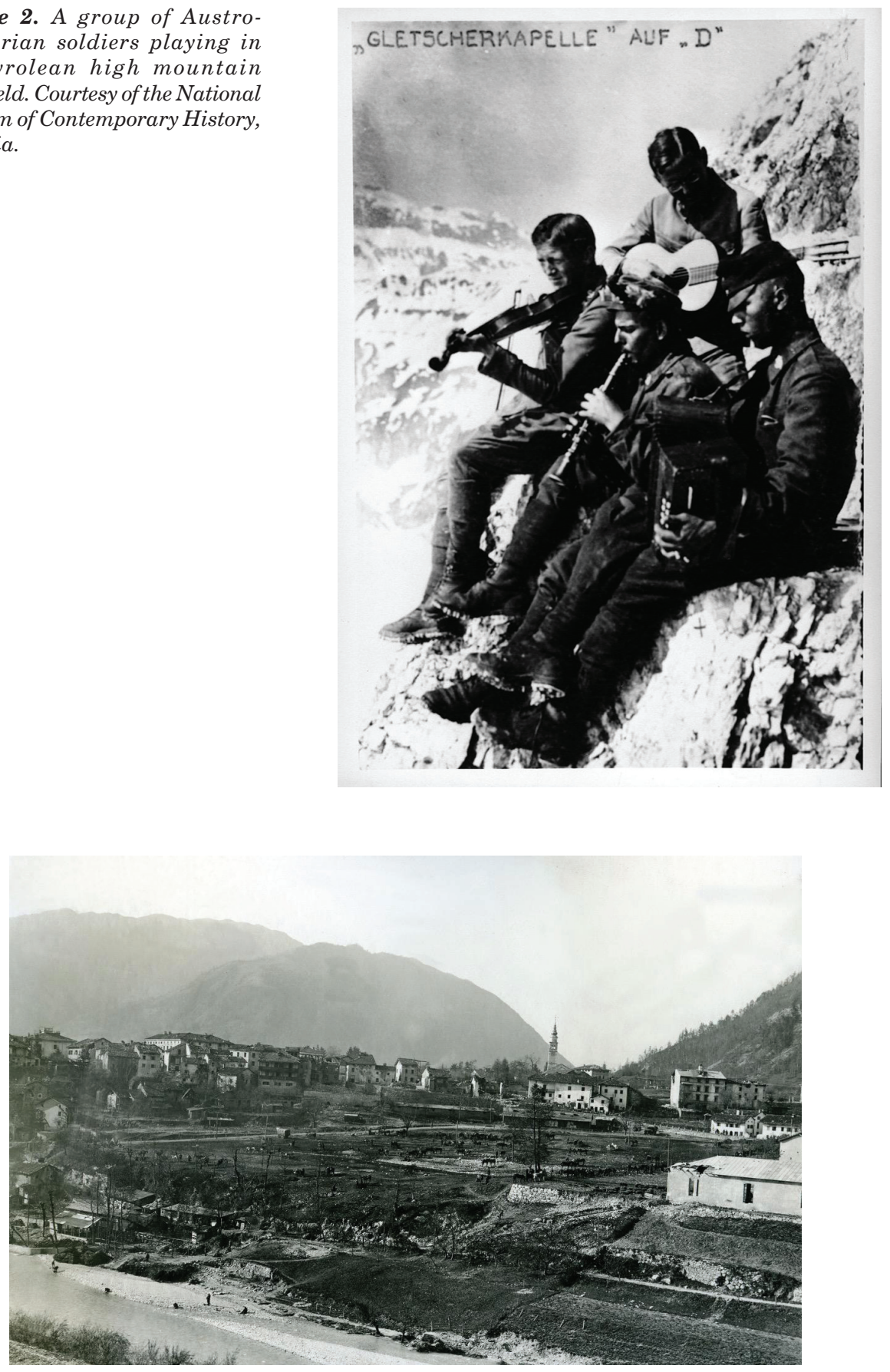

Figure 3. A view of the town of Tolmin, 1917. Courtesy of the National Museum of Contemporary History, Slovenia. 
identified on the basis of dealing with this topic - and thus taken into analysis are connected with one particular place. Therefore, the interpretation below deals with the specifics of this connection in each of the cases. Before turning to this analysis, however, I present the place itself, its connection with the Isonzo Front, and its war heritage, as well as its musical past and present.

\section{THE PLACE}

I start by presenting the blossoming heritage industry in the Soča Valley, Slovenia, where Tolmin is also located. Then, I present specific features of manifestations of popular music in the town of Tolmin, which are important for contextualizing the musical works analyzed.

\section{The making of the Isonzo Front as local heritage}

In Yugoslavia, war-related heritage was largely limited to the Second World War. My interlocutor, an employee at the contemporary Institute for the Protection of Cultural Heritage of Slovenia, reproduced the instruction given in the 1980s by the institute's head about how to handle the First World War battlefields: "Take notes on that, but don't present it publicly. The time's not right yet." Yugoslavia took care of preserving military cemeteries and monuments from the First World War, but not the remains of the battlefields because the battles that were glorified were those of the partisan antifascist resistance. However, a few locals in the Isonzo Front area were quite familiar with the remains of its battlefields and had accumulated considerable knowledge about them already in Yugoslavia. First of all, local people came into contact with military objects and remnants of the war built in situ while searching for scrap iron to sell for extra cash. This practice had a long tradition, extending into the interwar period, when the area was part of Italy. However, after decades of sharing knowledge about wartime debris lying in the mountains, a few people developed a stronger interest in military artifacts and became collectors and connoisseurs of both wartime events in the area and the local terrain. These persons accumulated large collections of various items that they stored in their garages, basements, and barns.

The independence of Slovenia in 1991 is considered a turning point regarding the memory of the First World War. A few events in the early 1990s marked this turning point, all connected with the Isonzo Front. ${ }^{8}$ The previous individual collectors of military paraphernalia joined together in a few locally active as- 
sociations dedicated to preserving the heritage of the Isonzo Front; for example, the association 1313 was founded in 1990. A war museum was established in Kobarid in 1990, and in 1993 it won the Council of Europe Museum Prize. The book Plavi križ (Blue Cross) by Vasja Klavora was published in 1991 and was an immediate success. Gradually, especially in Kobarid, where the museum was also economically successful, an entire heritage industry developed, today employing a considerable number of residents.

Importantly, for the centennial of the war (between 2014 and 2018) local associations, museums, and other institutions involved in (war) heritage (e.g., the Kobarid Museum, the Walks of Peace Foundation in Kobarid, the Tolmin Museum, etc.) became increasingly active. Firstly, this is because the anniversary was a timeframe that (local) war enthusiasts were eager to celebrate. Secondly, by referring to the centennial, heritage institutions could obtain fresh national and international capital for heritage preservation. Thirdly, by referring to the centennial, the heritage industry could expand its business by attracting new and wider segments of audiences and thus attracting more visitors. Crucially for this article, in the Soča Valley an outcome of this invigorated heritage process is the ubiquitous discourse on the Isonzo Front and an increased public awareness about the war (heritage).

\section{Local musical life}

Here I shift from heritage to local manifestations of popular music, which helps contextualize the emergence of the Isonzo Front as a topic of contemporary musical works by a few artists. First of all, the considerable geography of cultural production in the Soča Valley should be briefly outlined. Namely, whereas Kobarid has evolved into the local center of the war heritage industry since the early 1990s, Tolmin, which lies sixteen kilometers away, has been the musical center of the valley for decades. There is a music school in the town, and quite heterogeneous musical life has strongly marked the town.

The first popular music band in Tolmin that I was able to identify ${ }^{9}$ was active under the leadership of Emanuel Leban after the Second World War. At that time, Italian popular music was locally praised, and it has been influential in the area since the interwar period. When the Sanremo Italian Song Festival started in 1951 (which was broadcast on radio and soon also on TV), local musicians paid attention to it, accepted it enthusiastically, and copied its current hits. By 1953 Sanremo had a local copy outside Tolmin called Beneška noč (Venetian Night). However, immediately after this event the performing musicians' leader, Ivo Medved, was interrogated by the local Socialist Alli- 
ance of Working People of Yugoslavia for performing Italian popular songs. At a time when relations between Yugoslavia and Italy were hostile because of the unresolved border issue, the band was accused of bourgeois behavior, of thinking that true democracy lay in the capitalist state, and of not properly understanding socialist democracy - all of this for playing popular Italian tunes (Tul 2002). Nevertheless, Italian songs, and particularly the festival in Sanremo, remained popular in the area and also among local musicians in the decades that followed. Indeed, this influence had a long-lasting impact on local musical taste, which was less oriented toward Slovenian folk pop (narodnozabavna glasba, otherwise the most popular music among Slovenians since the Second World War) and more toward various "western" styles. In different historical periods, local bands were therefore eager to imitate Italian hits, but also twist, Slovenian pop music (slovenska popevka), and later on rock and roll and rock.

Local production of music was principally oriented toward imitation and making covers of popular songs, although a few local musicians, starting with Emanuel Leban, also composed original songs. This changed in the 1990s, when local heavy metal bands completely reversed the logic of music-making by dedicating their entire repertoires to original compositions. This gradually also became a standard in other locally present musical genres; for example, rock and blues. However, this process of reorienting the young generation of local musicians from cover songs to original songs was marked by an additional reorientation. Namely, quite a few songwriters turned away from "general" topics to express something distinctively local in their song lyrics. The place where the musicians lived - their hometown and its surroundings - became the central scope of creative engagement for many of them. Lyrics in local dialect and the use of specific local expressions were another prominent part of their musical expression of local belonging. In addition, they also contributed a few reinterpretations of local folk songs.

In the mid-1990s, three bands distinctively marked this local musical turn: Medrje, Blêd Bend, and Tminski Madrigalisti. Nevertheless, this musical localism was not limited to these three groups, but to a certain extent also marked other contemporary performers in Tolmin and its vicinity: Abarigani Mzurisanaa, Projekt Sotočje, Rodoljubac, and The Štrudls. Moreover, the echoes of this turn into locality have remained present on the local musical scene until the present. Today, for example, the rap musician Iaria prominently continues it. In addition, Rodoljubac and Bakalina, which I analyze below, also preserve this legacy, and their interest in the First World War, which has recently become a prominent local topic, should also be understood in relation to this musical localism. 
Before I turn to concrete cases, I briefly present my explanation of this local musical phenomenon, which is an explanation relying on spatial analysis. As I discussed elsewhere (Kozorog 2010, 2011), in the early 1990s something crucial occurred on the youth scene (and the related music scene) in Tolmin. Namely, along the Soča River two venues were established by young people themselves, which enabled them to freely express their enjoyment of place-based autonomy. For young people, the venues crucially reorganized local space and became the "background" (Hirsch 1995: 3-4) for a completely new sense of place. The venues introduced a new angle from which young people could perceive their hometown, which from their point of view was transformed from a dull "hole" into a place marked by distinctive venues located in aesthetically pleasing locations along the river. For example, the song “The Tmin's [Tolmin] Summertime Rock'n'Roll" by Blêd Bend enthusiastically describes the two venues and the freedom enjoyed there by the young. Young people's autonomous production of place (i.e., the venues of making and organizing) and space (i.e., practicing the town, sensing it, positioning it in broader geographies, etc.) stimulated its local identification, and consequently the expression of this identity in music. In addition, musical representations of place also contributed to its production; namely, through a specific description of the place in young people's own terms (cf. Cohen 1995).

In addition to enjoying the venues themselves, local young people were eager (and perhaps proud) to host like-minded people from elsewhere, which led to an artistic festival called Sajeta in 1998. Its aim was to create collaborations between local and foreign artists by hosting the latter. This festival is still being held today, ${ }^{10}$ and part of Bratko Bibič's project discussed below was produced within the framework of this festival.

\section{THE OPTIONAL, THE SENSITIVE, AND THE STUDIOUS}

This section presents musical works dedicated to the Isonzo Front, composed by Rodoljubac, Bakalina, and Bratko Bibič. I conducted interviews with the musicians, asking them about the circumstances that led them to compose their music, about the musical components and textual part of their musical works, about their personal relation to the war, about their relation to the Soča Valley, and about their collaboration during the centennial of the war. ${ }^{11}$ The following subsections present each performer and relevant compositions as well as the circumstances of their creation. I also point out the musicians' attitudes to the place. Then I conclude by referring to differences in ways of knowing the place, which stimulated three different portraits of this locally fought war. 


\section{"A Farewell to Arms"}

The band Rodoljubac performs garage rock and roll with elements of heavy metal music. The band was formed in 1996 (I was among the founding members of this band) as part of the aforementioned locality-oriented Tolmin music and youth scene, and so far it has released five albums. The principal characteristic of the band is parody, which is primarily directed towards popular music genres and the music industry, but also broader society and the band itself. Their song examined here is "Zbogom orožje" (A Farewell to Arms), named after the novel by Ernest Hemingway, which contains references to the Isonzo Front.

"A Farewell to Arms" - recorded in 2015 and released on the album Rodoljubac in 2016 - was not the band's first song dedicated to history. In 2008, the band released the album 1713 , containing a song with the same name, which refers to (the year of) the Tolmin peasant rebellion. As a matter of fact, history is rare among the band's themes, but when it is there, it is a place-bound history. When I asked about the motive for writing a song about the First World War, I received the following explanation:

Rock bands often have epic or historical songs, but they usually say stupid things. For instance, bands praise invented battles or battles from I don't know where, whereas us, we live here in an area where still, every day you can see consequences of the war, and we therefore decided, first, to work on the Tolmin peasant rebellion of 1713, and then - what else could we work on about Tolmin? - well, the First World War! ... After so many years of making music, sometimes you don't find the right inspiration. So, maybe we saw other bands singing about wars, ${ }^{12}$ yet completely empty, so we said, why not write a song about our surroundings because we really have something to sing about. (Davor Mrak) ${ }^{13}$

As is the case with quite a few residents of the Soča Valley, one of the band members has demonstrated a greater passion for the history of the Isonzo Front, so he wrote the song's lyrics. Yet the decision to represent the war was a collective one. One of the band members explained to me that the war heritage has become an integral part of the local environment, and so "everyone who's living in this area has an attitude toward the war, although everyone has a different one". Another band member, Davor Mrak, whom I interviewed, described to me the process of finding consensus about the song. From his narration, it follows that the song is more an outcome of a certain sense of place, containing knowledge about the war, nowadays broadly shared in the Soča Valley, than it is a result of a single member's (i.e., the lyricist's) passion for the Isonzo Front. 
After writing the lyrics, it took some time before the music was composed and the song finished, recorded, and released. The band decided on a heavy metal style, rather than rock and roll, because slow and heavy riffs seemed more appropriate for the war theme. Although the decision to produce the song and the process of recording it was detached from the centennial of the war, the centennial nonetheless influenced its recording and release. Namely, when Rodoljubac was in the recording studio in 2015, it turned out that the centennial of the date when the Kingdom of Italy declared war on Austro-Hungary - which coincided with the opening of the Isonzo Front - was quickly approaching. This convinced the band to finish the song, which was then released on YouTube on May 21st, 2015, two days before the centennial. Hence, the anniversary was the trigger that convinced the band to release this song before all the other songs from the record. The song was then released on CD together with others a year later.

The song's lyrics are set around the events that led to the collapse of the Isonzo Front. They say that Mounts Škabrijel, Batognica, and Krn were a "bloody thorn" for the combatants, but then the "miracle of Kobarid" happened, as the battle between October 24th and 27th, 1917, is colloquially called, which forced the Italian army to withdraw from the Soča to the Piave River. It also mentions the role of the renowned Lieutenant Erwin Rommel in this battle and his breakthrough over Mount Kolovrat above Tolmin. However, during the recording session, a dispute broke out in the band because one member thought that the song was one-sided, ridiculing the Italians. In the studio, the band even wrote an alternative, more balanced version of the song, but then nevertheless decided to keep the first version. The reason for this was the argument that the Soča Valley was Austro-Hungarian at that time and hence, at least in the band members' perception, even today locals praise the Austro-Hungarian side more than the other side in the war.

Nonetheless, the song portrays the war in what may be politically incorrect terms: "On the Austro-Hungarian side our grandfathers were slaughtering / Borojević was their general / Many gave their lives / Instead of lying in their beds at home with their women." The text is in local dialect, but the refrain is sung in broken German: "Hilfe mich o meine Mutter, warum wurde ich ein Kannon Futter" (Help me, oh, my mother, why am I cannon fodder?). When I asked Davor Mrak where this phrase came from, I received the answer:

The war was tragic, but the song contains some of our typical dark humor. That German soldier up there wouldn't ask himself this in such a way. Kannon Futter sounds a bit funny in this context. We kept it to soften everything a little bit. A person listening to this song should know us to understand why we present things not too seriously. 


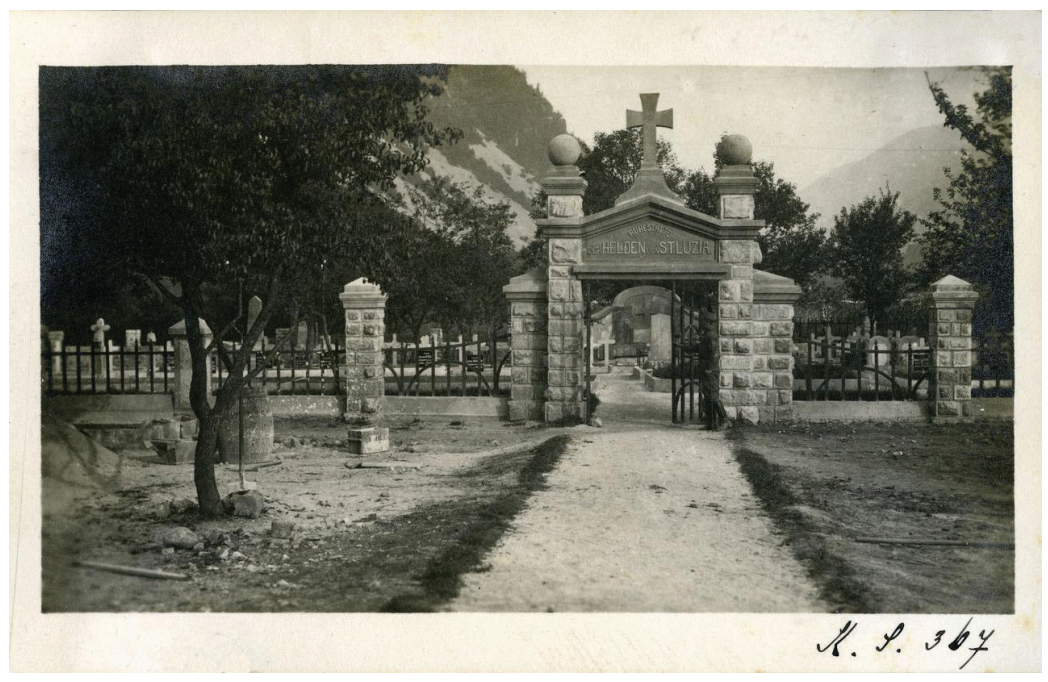

Figure 4. Austro-Hungarian military cemetery St Lucija, now Most na Soči. Courtesy of the National Museum of Contemporary History, Slovenia.

According to him, the gallows humor that the band cultivates is actually part of local character, which might have its roots even in the events of the First World War:

The sense of humor we have in Tolmin is specific and could be an outcome of historical events in this area. The conditions were certainly hard and people had to adapt in order to survive. This is perhaps why a more ironic and dark sense of humor developed here, which is characteristic of people in these surroundings. For the people the war was a huge trauma and it changed the course of life enormously, we cannot even imagine it, so they had to patch up the situation somehow, and I think our character has been shaped by those wartime events.

One can observe in Rodoljubac's presentation of the war both respectfulness (the song finishes with the following lines: "Many [soldiers] gave their lives / In the Soča Valley forever they remained") and an unburdened, distant, and optional view of the wartime events. Whereas the lyrics maintain a distance from how the war was felt by its contemporary participants (soldiers and civilians), it reproduces a present local perspective on the war, which is usually limited to familiarity with the major historical events in the valley (e.g., major battles). 
Moreover, in addition to reproducing the local perception of the war, the band also remained faithful to the characteristics of the heavy metal genre and especially its own (again interpreted as local) expression of gallows humor. The band's representation of the war could therefore be summarized as an outgrowth of broader contemporary events and discourses in the Soča Valley, where especially in the recent centennial years the Isonzo Front has become omnipresent - that is, a part of the local social atmosphere from which Rodoljubac has always drawn its inspiration.

\section{"The Letter"}

The two performers of the duo Bakalina, which has released four albums since 2009, are: Renata Lapanja on accordion, and the vocalist and songwriter Jani Kutin. They live in two mountain villages around Tolmin. Bakalina performs original chansons, resembling Slovenian traditional folk songs. The lyrics, written by Kutin, are in the local dialect, depicting local rural life, and in many cases containing a moral (sometimes with plenty of humor and irony) about the destructive ways of contemporary living in contrast to (in the songwriter's view) the more righteous life in the past. Before establishing the duo, Kutin was a member of quite a few musical collectives and projects, among them The Štrudls, who were among the early local bands reflecting on local matters in the local dialect. Kutin has written two songs dedicated to the Isonzo Front: "Rdejč ruob" (Red Rim), named after the mountain in front of his home village of Čadrg, where there was a battlefield during the First World War, and "Pisma" (The Letter), which portrays a soldier writing to his mother.

There is a stark contrast between these songs and the one by Rodoljubac. There is not merely a musical difference between the heavy guitar riffs and gloomy melodies of the accordion, but also the point of view of the narrator is entirely reversed: whereas Rodoljubac provides a distant gaze of a contemporaneous native observer of historical local events, Bakalina builds on a personal impression of the war by a war participant: a soldier. In "Red Rim", released in 2011, the course of a soldier from home to the Isonzo Front is described. Observing human tragedy, this soldier loses his soul: "He cried out loudly / But not because of pain / Much more because of sorrow. / What beautiful was, died / It only was a memory / Darkness fell on eyes." Although the narrator describes the soldier's states of being as observer, a feeling of intimacy is provided in order to produce identification by the listener with the soldier's personal tragedy. Even more personal is "The Letter", released in 2016, where the listener hears a confession of a soldier to his mother. In this song, the soldier's soul has 


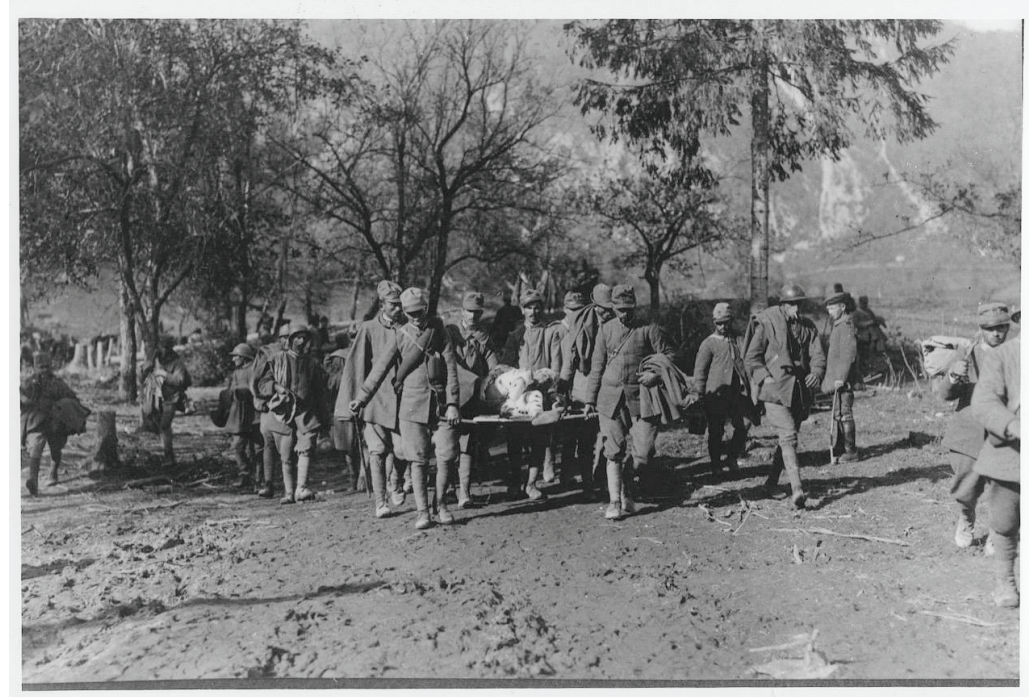

Figure 5. Italian prisoners of war in Zatolmin. Courtesy of the National Museum of Contemporary History, Slovenia.

died by abandoning everything human that his mother taught him: "Don't wait for me mother / I don't find peace anymore / I've died inside. / I only beg you mother / Pray for all those / Who cannot go home." The refrain is the soldier's repetitive yearning: "I'd like to go home." This phrase, which is backed up by a male choir on the recorded version, affects listeners' compassion.

This specific mode of depicting the war as a human and personal tragedy is rooted in the songwriter's experience of remnants of the war. Kutin is a farmer, the successor at a family farm, who knows the area around his home village quite well. He also remembers stories told by his grandfather about wartime events in the vicinity, and he recalls his first contact with remnants of the war: "My brother and I have been collecting antiques since we were little kids, including military paraphernalia. We found one whole gun, down under a rock, when we were around ten." As a child he explored the nearby slopes, gorges, mountains, and abandoned households. In addition, collecting remnants of the First World War was also present in the family:

Two of my uncles were collecting. One still collects a bit, but he never had a private museum or anything, the other is already dead, and was addicted to this [practice], he was also unmarried, and sadly he died because of this hobby. A grenade [that he found in the ground] exploded. 
After this accident, Kutin gave up collecting military items and instead dedicated his collection to farm implements:

As kids we were very interested in the war, well, in the remnants of the First World War. ... But as a kid you don't think what war is in reality. ... Other people my age were collectors too. Young people in the village of Zatolmin have many home collections. I still know many who go out to dig with metal detectors every day, up and down. They dig out artifacts and that's their greatest pleasure. And I understand this less and less.... At the same time, I think we're talking far too little about the suffering and consequences of the war. ... Well, I've always felt this very much. Of course, the whole Tolmin area is impregnated with this feeling, which hasn't entirely left this valley in a hundred years. You can't dismiss it as if nothing happened, if you've got at least some sensitivity. So, in my opinion the songs I've written emerged very spontaneously, as a confession, so that I gave away my feelings about the war, without wanting to dramatize it.

This musician has had intense relations with war-related phenomena in the area. He explored military structures and listened to stories about wartime events as a child, he has been observing and experiencing local collecting practices and their consequences, he has been engaged with the local landscape, which is not only used for farming, but is also the bearer of the memory of a difficult history, which makes him think about the wartime events that took place there, and he also senses the remnants of the war as still radiating a specific feeling of wartime suffering (cf. Navaro-Yashin 2012). Importantly, however, Kutin is a farmer, who regularly works outside, where he is in direct contact with the landscape where the war took place. For example, the mountain after which he named his first song about the Isonzo Front rises high opposite his house:

It's a big mountain, especially when seen from Čadrg. It's paramount. And if you look at it all your life and if you're connecting it with the war, you can't overlook it. ... And it helps imagine what a severe environment they [the soldiers] were pushed into. Those cliffs, freezing, in a condition without hope, and besides all this they had to fight. Well, it was really bad.

His second song was also stimulated by his sense of place. He was inspired while visiting the Church of the Holy Spirit in Javorca, in the Tolminka Valley, just below his home village. It was built during the war by Austro-Hungarian soldiers, just behind the frontline at the mountain that Kutin used as a motif in his first song: 
I remember when I came to Javorca as a kid. This church means a lot to me. Maybe because it's the church closest to our village and so every time there was a mass we went there to attend mass. ... But I've always felt ... I experienced this place very strongly. Someone will look only at the architecture, and yes, it's a very beautiful church. But you can't overlook all those names [of dead soldiers, which are engraved on the church's walls]. And although they aren't buried there, their names are so strong. ... Really, I see Javorca every time I'm at the edge of the village. It's such a prominent spot, which always makes me ... And when I was writing this second song, 'The Letter', I remember exactly the moment when I got the idea for this song. I was cutting grass below the village, from where you can see Javorca, and I was cutting, and this melody just appeared, and the refrain 'I'd like to go home', and then when I sang the first two lines when I started to write it down, the song was so strong that tears came to my eyes. I knew that that was it, because such moments don't come so often that you feel one song so strongly already when you're creating it. It came directly from the place.

Because this specific location inspired the song, the songwriter demanded that they record it in Javorca, which was a special experience, as he recalls: "We felt the presence of those soldiers while recording". The decision to record it at Javorca was also made on the basis of the duo's previous musical experience of this place. Namely, in 2014, the accordion player Renata Lapanja, again on the basis of her personal sense of the place, held a concert there entitled Benevolent Concert for Peace. This concert was partly dedicated to the centennial of the war, but organized spontaneously, not as an official celebration of the anniversary. ${ }^{14}$ On this occasion, Bakalina performed "The Letter" for the first time: "It was a very special feeling. ... And that was one of the first events dedicated to the centennial" (Jani Kutin).

Nonetheless, Bakalina's songs were not composed because of the centennial, but in spite of it. The primary motivation for the duo to dedicate their works and concerts to the memory of the war came from their personal sense of the local landscapes as material preservers of the suffering in the region in the past (cf. Saunders 2001). The songs thus sprang from a specific perception of places that were settings of wartime events. At the same time, the duo continues to carefully reflect on the places where these songs are performed. For example, when invited by heritage agents in Kobarid to perform "The Letter" at the main event marking the centennial of the Isonzo Front, Bakalina refused to take part because the event was based on a reconstruction (or performance) of a historical battle: 
We have a poor awareness of today's wars. They are different, but they exist, and people suffer the same. ... Why collaborate in an event where thousands of euros are spent to staging a hundred-year-old battle? Man, nearby in Gorizia, we have I don't know how many thousands of refugees in catastrophic conditions. Nobody is aware of that, and nobody helps, and it's getting worse as I hear. For a while, there was compassion, but now it goes on without anyone saying anything. So, we refused this performance for this reason. (Jani Kutin)

\section{Javorca: Resurrection}

Bratko Bibič is a musician that has been subverting Slovenian popular music and culture since the 1970s. At that time, he established the avant-garde band Begnagrad, which partly relied on the Alpine folk-pop musical culture, overturning it with rock-in-opposition and jazz elements. The band was controversial for using what was at that time the allegedly "out of fashion" accordion in the field dominated by electric guitars and progressive composition (cf. Bibič 2014). As an accordion player and composer, Bibič then also became internationally active through collaboration in the rock-in-opposition band Nimal and the accordion "supergroup" Accordion Tribe. Moreover, as a soloist he combined music and other artistic forms. He dedicated a piece of work to Slovenian film heritage, combining archival research, film montage, and composition. In addition, as sociologist and philosopher, he has also been working as a researcher, an important field of his enquiry being urban politics and the social production of space (Bibič 2003).

His work on the Isonzo Front also combines archival and conceptual research, musical composition, and interlacing of artistic forms. The work, dedicated to the aforementioned church in Javorca, deals with the rear areas of the front, where during the war everyday life - music and entertainment included was established. The Church of the Holy Spirit was built in 1916 by AustroHungarian soldiers (i.e., during the war for a spiritual purpose), and today is regarded as a unique piece of Secession architecture in the Slovenian Alps. It stands in Javorca, a low ridge in the Tolminka Valley (close to the source of the Tolminka River), surrounded by a chain of high mountains. Bibič, similarly to Kutin, describes the church and its location as "suggestive". It has a unique architecture, also because the names of dead soldiers are engraved on wooden panels, which hang from the walls inside the church, symbolizing a memorial book. Bibič recalls that these names already fascinated him as a child. 


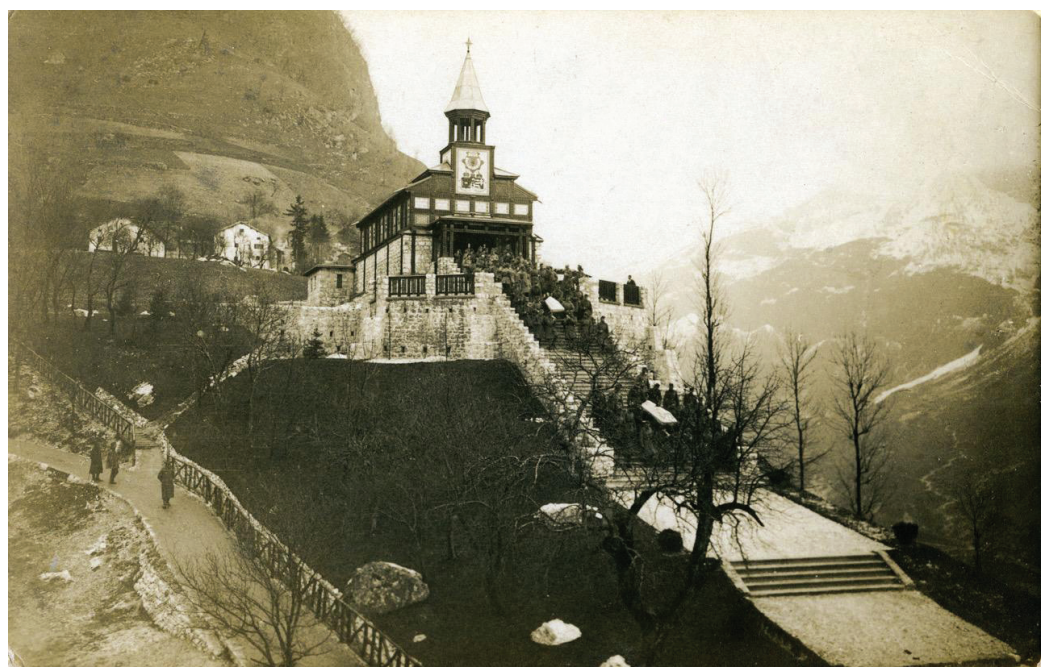

Figure 6. Holy mass for fallen soldiers in the Church of the Holy Spirit on Javorca. Courtesy of the National Museum of Contemporary History, Slovenia.

His work on the project Javorca: Resurrection started in 2009, and has gone through several phases. Initially he wrote a script for a multimedia performance, which turned into a synopsis for a film. Because of a lack of funds to produce a film, he composed a cantata, performed at the Cerkno Jazz Festival as Javorca: Quasi una cantata (Javorca: Almost a Cantata) in 2010. He then developed it into the multimedia project Javorca: resurekcija (Javorca: Resurrection), which was performed in the church at Javorca as part of the Sajeta festival in 2016.

Bibič grasps the church (or what it represents) in its complexity; that is, by relating history, contemporary heritage regimes, and the dead, preserved in the names on the church's walls. The core protagonist in the initial script of the project is a child, whom the Good Soldier Švejk leads through an Alpine area, wittily called a "natural history park". The script presents this "protected area" as subordinated to flourishing regimes of heritagization and touristification. At the same time, it is a setting for a circus, which during the war toured the rear areas of the front. Its protagonists are all dead today, but they continue to perform for the park's visitors, and thus Švejk and the child enjoy their show. The perspective on the "protected area" is thus an uncanny combination of entertainment and piety.

Although the artist relies on the figure of a child because it represents curiosity, there is also another, personal reason for this. Bibič is a native of 
Ljubljana, but his mother a native of Zatolmin, a village between Tolmin and Javorca. Because both of his parents worked in education, he remembers that in the 1960s the family spent entire summers in Zatolmin, where, in addition to enjoying the long school vacations, he was involved in his relatives' farming. He recalls that his first contact with the Holy Spirit Church, eight kilometers distant from Zatolmin, probably took place as part of this vacationing, when the family stayed in a lodge in the mountain pasture, located near a shooting range in Javorca. More important, however, was an experience in the late 1960s. When he was about ten years old, and as part of his ordinary exploration of the area at that time, he ventured from Zatolmin into the Tolminka Valley alone. This expedition turned into a powerful childhood memory, which he describes as follows:

You don't clearly recall many things from your childhood. They have to be powerful. I will remember for my whole life how I stepped out ... That was the time when the surroundings [of the Church of the Holy Spirit] were overgrown and the church was in ruins. It was in its worst condition ever. ${ }^{15}$ I probably took a shortcut towards the church. I remember when I stepped out from the bushes, and I was standing right in front of that big staircase that leads towards the church. And the stairs were partly in ruins; they were broken, ruined, and overgrown with brambles. But on those stairs there were some twenty snakes sunning themselves. Adders, vipers, who knows what. I stepped right in front of them. So, I have this memory: that staircase, which is monumental, especially for a small kid, partly ruined, and about twenty curled up snakes on it, sunning themselves.

This powerful experience is one thing he remembers as crucial for his further investigation of the war. The other thing he mentions is his fascination "with the whole ambient of the First World War, which was then [in his childhood] completely untouched or, in other words, nobody was occupied with that. For a boy, war is often fascinating, and I was fascinated by that complex of bunkers in the Tolminka Valley and other remains there". Like Kutin, he too mentions his own finds of military objects close to the house, where he was on vacation.

Yet, unlike Kutin, he was living elsewhere, detached from the local landscapes. His later dealing with the place has thus primarily been contemplative. He has been reflecting on his own experiences of the remnants of war as well as on the war itself largely through philosophical, sociological, and artistic prisms. His treatment of the war, for example, reflects on various layers of space (i.e. material, symbolic, and experiential), which he was familiar with from his previous research on the production of space and urban process (e.g. Bibič 2003). This research provided him with solid conceptual tools for 
thinking about what he calls "urbanization of the Alps through the war". In this regard, he describes the war as bizarre because destruction went hand in hand with building infrastructure in previously undeveloped areas (which were commonly understood as "natural"), like the Alps. Thus, for example, the Austro-Hungarian army built the road connecting Zatolmin and Javorca (i.e., the one that Bibič used for childhood exploration) for the purpose of war; that is, for supplying the front.

At the same time, Bibič's composition deals with many other aspects of the war. Thus, for example, he contextualizes the particular location in relation to broader contemporary social processes, especially by referring to avant-garde artistic movements - futurism and dada - occurring not far from the frontline between Italy and Austro-Hungary. Again, he received an impulse to investigate these aspects of the First World War from his previous research, this time on Walter Benjamin (Bibič-Faninger 1991). Namely, Benjamin's essay titled "The Work of Art in the Age of Mechanical Reproduction" refers to Marinetti's glorification of war in order to present ideas on aesthetization of war and politization of art. Bibič uses various outstanding quotes (e.g., from Hemingway's A Natural History of the Dead, which states: "They had beautiful burying grounds in the mountains, war in the mountains is the most beautiful of all war...") as well as archival audio materials: recordings of singing soldiers (e.g., from Judenburg); part of Stravinsky's L'histoire du soldat (The Soldier's Tale), which he wrote in Switzerland during the war; and a cantata dedicated to the Soča River from 1916, which the Slovenian composer Hugolin Sattner based on a famous poem by the Slovenian poet Simon Gregorčič. Among other narratives, the names on the church's walls are recited in the composition. The apparatus that Bibič developed to interconnect historical events, the place, built and natural environments, personal memories, philosophical references, metaphorical derivations, and so on, is thus much too complex to allow adequate reproduction here. What I would like to highlight, however, is his ways of knowing the place, which on the one hand contain memories of personal experiences of the place, and on the other various theoretical and artistic approaches to comprehension of place and space.

After Bibič publicly presented his work about Javorca, his cousin reminded him that he had been saying for a long time that he would compose a cantata composed of the names on the church's walls. The fact that this artistic impulse coincided with the centennial was largely a coincidence, as he wittily remarks:

I started the project in 2009 simply because I received a grant from the Slovenian Ministry of Culture. ${ }^{16}$ Marinetti wrote the futurism manifesto in 1909. Hence, if any centennial coincides with my project, is the 
centennial of futurism. [Laughs] Merely a coincidence. ... Whereas in 2016, when I made the last version, it was coincidently a centennial of Cabaret Voltaire and dada. [Laughs].

In 2016, however, when national and local authorities and heritage promoters celebrated the centennial of the church in Javorca, the organizers of the Sajeta festival in Tolmin used this opportunity to invite Bibič to develop his artistic work as part of the festival and its international project, entitled Echoes from Invisible Landscapes. The performance of Javorca: Resurrection in the church in Javorca was very ritualistic, ${ }^{17}$ which was another of Bibič's comments on and subversion of the multitude of rituals appearing locally for various centennials of the war.

\section{CONCLUSION}

I have presented three recent Slovenian popular music works dedicated to the Isonzo Front. Musically they do not share many things; they are aesthetically and conceptually very different from each other. Doubtlessly, the commitment of musicians to their own aesthetics and concepts played an important role in their music-making and informed the modes of representation of the selected theme. However, more than to aesthetics, I have paid attention to the procedures of establishing the First World War for their theme because this has hitherto been largely neglected in Slovenian popular culture. Specifically, I was concerned with the role of their knowing a particular war-related place in their construction of the theme. Namely, each of the musicians presented is connected to the Tolmin area in one way or another, which is on the one hand marked by rich local musical life and on the other by gradually intensifying heritagization procedures and centennial celebrations. Most of the members of Rodoljubac and Bakalina live there, whereas Bratko Bibič experienced this place as a child. However, because their practice and their experience of the place vary, my core question is whether differences in the ways of knowing a place engender differences in representations of that place and its history.

The cases presented demonstrate that four ways of knowing the place contributed to the musical works examined. In the case of Rodoljubac, most of the members were not especially engaged with the war, although one of them showed a greater interest in the local legacy of the war. They have primarily been involved in common discourse on the war, which nowadays produces a specific local social environment that - increasingly during the centennial years - cultivates a narration about the involvement of "their" place - that is, 
the place they identify with - in the war. The war has become an integral part of the contemporary social process in the town of Tolmin, where its residents superficially know its history, but are constantly exposed to the present manifestations of war, which find their place in public events and mass media reports, but also in everyday conversations by fellow residents. However, usually the residents know only a few things about the war (e.g., the major events), which is reflected in the representation by Rodoljubac. As a band that has devoted some of its works to locally important topics, it also decided to dedicate part of its work to a war fought locally, which it represents by the major battle that led to the collapse of the Isonzo Front.

Quite differently, Jani Kutin from Bakalina investigated the local landscapes as a child and has remained connected to them as a farmer. He perceives the landscape as full of remnants from the war (i.e., objects in the ground, monuments like Javorca, and ruins), which he primarily associates with human suffering. He contemplates these landscapes as though they are alive, as if the material world he is in daily contact with keeps on preserving the experience of those that went through the tragedy of the war a hundred years ago. His everyday observation of - and movement through - such landscapes thus stimulated him to produce words and a melody for a song representing the presumed inner feelings of a soldier.

In a way, Bratko Bibič's direct experience of the place and its landscape is similar to Kutin's, yet his experience also contains a temporal and spatial distance. Moreover, although childhood memories stimulated him to return to the place as an acknowledged artist, he also relies on other ways of knowing the place; namely, on various approaches to studying it. Through these approaches, he loads upon the place many layers of meaning, some referring to theoretical conceptualizations of place and space, and others to artistic metaphors he has developed. His Javorca: Resurrection is a meshwork of history, memory, and the present oversupply of heritage regimes, in which tourism plays an integral role. This representation of place and the war also critically reflects on the contemporary processes of place-making, in which the dead are reanimated to serve the demands of today's economy for the production of alluring places.

The cases thus confirm the thesis behind my inquiry that different ways of knowing a place have played an integral role in engendering different musical representations of the place and its wartime history.

However, let me conclude with another, less relevant inquiry of my investigation - that is, musicians' collaboration in the centennial celebrations. As already mentioned, such celebrations are part of the present experience of the place because policymakers have recognized the centennial as an opportunity for branding the place. As also mentioned, this social atmosphere was in one 
way or another involved in the creation of three musical works. However, were the musicians also involved in the celebrations? My interlocutor from Rodoljubac says that this was not the case because policymakers perceive the band as a representative of local underground culture. Hence, they will most likely remain unnoticed by such agents. Bratko Bibič, on the other hand, presented Javorca: Resurrection as a centennial event. However, this event was held by an alternative culture organization (i.e., the Sajeta festival), which made possible a reflexive and critical contextualization of war anniversaries. Bakalina was invited to perform as part of a central centennial event whose core component was a battle. The organizer invited the duo in order "to soften the experience of the battle a bit". For ethical reasons, Bakalina refused to participate, although it has been involved in other, less explicitly militant, centennial events. Indeed, these artists are attentive to the ways they present their work dedicated to the war. They dealt with ethical questions already while composing their works, and they are well aware of the moral ambiguity of contemporary celebrations of the centennials.

\section{NOTES}

1 The article is based on research carried out for the research project titled Heritage of the First World War: Representations and Reinterpretations (2016-2018), funded by the Slovenian Research Agency (No. J6-7173). For more information about the project, see Jezernik \& Fikfak 2018.

2 Ethnologists, ethnomusicologists, music folklorists, anthropologists, and other researchers have shown on a number of occasions that the distinction between popular and folk music is problematic. I use it loosely; that is, in its conventional sense, to distinguish between music made with reference to mass media (i.e., popular music) and music performed and transmitted detached from the mass media context (i.e., folk music).

3 See https://neubauten.org/en/lament, last accessed on 24 September 2018.

4 The river is known as the Isonzo in Italian and the Soča in Slovenian. It rises in the Julian Alps in Slovenia and empties into the Adriatic Sea in Italy.

5 Itinerari della Grande Guerra - un viaggio nella storia (see http://www. itinerarigrandeguerra.it/it/29640/Le-canzoni-della-Grande-Guerra, last accessed on 24 September 2018).

6 Canzoni contro la guerra (Anti-war songs) (see https://www.antiwarsongs.org/canzone. php?id=47\&lang=it, last accessed on 24 September 2018).

7 The Habsburg Empire established permanent recruitment districts already in 1771, which led to ethnical and language uniform regiments, "which facilitated and at the same time constrained group singing” (Klobčar 2007b: 39). 
8 This also partly explains why, in the public imagination in Slovenia, the First World War is associated above all with the Isonzo Front and not with other battlefields of the time.

9 For more information about the history and social aspects of musical production in Tolmin, see my bachelor's thesis (Kozorog 2002), inspired by anthropological works on the complexity of local musical life (Finnegan 1989; Muršič 2000).

${ }^{10}$ In the interest of full disclosure, I was the festival's program curator from 2002 to 2010.

11 Three ethnographic interviews and additional conversations with those involved were carried out in July 2017.

${ }^{12}$ I can mention two other examples of the First World War representations in heavy metal music. In 1995, the Colombian metal band Neurosis released an album named after a Western Front battlefield: Verdun 1916. Allegedly, at the same time as Rodoljubac (but independently), the Slovenian heavy metal band Requiem from Ljubljana released a song dedicated to the First World War.

${ }^{13}$ I have mentioned the names of the interlocutors with whom I conducted official interviews. I refer to other members of Rodoljubac as to band members.

${ }^{14}$ Increased awareness of the war in the area is a social context that, as in the case of Rodoljubac, should not be neglected.

15 The church was renovated in the early $1980 \mathrm{~s}$.

16 The grant was not defined by the content of the artistic project.

${ }^{17}$ For example, Bibič involved spatial components in the performance. The composition was performed by four musicians in the church when no audience was present. In real time, it was - together with mixed-in texts and photograph animations - audiovisually streamed via satellite to a large screen for the audience at the confluence of Tolminka and Soča Rivers. The performance of the musical work was thus connected with the source of the Tolminka River, where the church was built during the war, while the work's reception found its place at the river mouth, where the battles took place.

\section{REFERENCES}

Bibič, Bratko 2003. Hrup z Metelkove: tranzicije prostorov in kulture v Ljubljani. [The Noise from Metelkova: Transitions of Spaces and Culture in Ljubljana.] Ljubljana: Mirovni inštitut. Available at http://www2.mirovni-institut.si/slo_html/ publikacije/pdf/MI_politike_hrup_z_metelkove.pdf, last accessed on 24 July 2018.

Bibič, Bratko 2014. Harmonika za butalce: ulomki iz življenja nekega glasbila. [Accordion for Dummies: Fractions from the Life of a Musician.] Ljubljana: Beletrina.

Bibič-Faninger, Bratko 1991. Elementi za branje del Walterja Benjamina. [Elements for Reading the Works of Walter Benjamin.] Anthropos, Vol. 23, No. 4-5, pp. 81-97. 
Carrera, Alessandro 2001. Folk Music and Popular Song from the Nineteenth Century to the 1990s. In: Zygmunt G. Baranski \& Rebecca J. West (eds.) The Cambridge Companion to Modern Italian Culture. Cambridge: Cambridge University Press, pp. 325-335. https://doi.org/10.1017/CCOL0521550343.018.

Castelli, Franco 2009. "Compagni dai campi e dalle officine": Appunti sul canto sociale e politico in Italia. Quaderno di storia contemporanea, Vol. 46, pp. 119-169. Available at http://www.isral.it/web/pubblicazioni/qsc_46_06_castelli.pdf, last accessed on 24 July 2018.

Cohen, Sara 1995. Sounding Out the City: Music and the Sensuous Production of Place. Transactions of the Institute of British Geographers, Vol. 20, No. 4, pp. 434-446. http://dx.doi.org/10.2307/622974.

Connell, John \& Gibson, Chris 2003. Sound Tracks: Popular Music, Identity and Place. London \& New York: Routledge.

Feld, Steven 1982. Sound and Sentiment: Birds, Weeping, Poetics, and Song in Kaluli Expression. Philadelphia: University of Pennsylvania Press.

Finnegan, Ruth 1989. The Hidden Musicians: Music-Making in an English Town. Cambridge: Cambridge University Press.

Hirsch, Eric 1995. Introduction. Landscape: Between Place and Space. In: Eric Hirsch \& Michael O'Hanlon (eds.) The Anthropology of Landscape: Perspectives on Place and Space. Oxford: Clarendon Press, pp. 1-30.

Hofman, Ana, \& Pogačar, Martin 2017. Partisan Resistance Today? The Music of the National Liberation Struggle and Social Engagement. In: Miha Kozorog \& Rajko Muršič (eds.) Sounds of Attraction: Yugoslav and Post-Yugoslav Popular Music. Ljubljana: Ljubljana University Press, Faculty of Arts, pp. 21-39.

Jezernik, Božidar \& Fikfak, Jurij (eds.) 2018. Cultural Heritage of the Great War. Traditiones, Vol. 47, No. 1. DOI: 10.3986/Traditio20184701.

Klobčar, Marija 2007a. The Expressiveness of Traditional Slovenian Military Songs. In: The Regiment Is on the March. From the Archives of the Institute of Ethnomusicology. Ljubljana: ZRC SAZU, pp. 3-43.

Klobčar, Marija 2007b. Fear and Courage in Traditional Slovene Military Songs. Slovene Studies Journal, Vol. 29, No. 1-2, pp. 35-55. http://dx.doi.org/10.7152/ ssj.v29i1.14031.

Kozorog, Miha 2002. Glasba-prostor-identiteta: primeri iz Tolmina po letu 1945. [MusicSpace-Identity: Cases from Tolmin After 1945.] Bachelor's thesis. University of Ljubljana.

Kozorog, Miha 2010. "Pa Tminu se patiepaje": življenjski svet lokalne skupnosti mladih v uglasbenih besedilih. Prvi del: uglaševanje. ["The Ramble around Tolmin": The Life-World of a Local Youth Community Reflected in Lyrics. Part One: Tuning.] Glasnik SED, Vol. 50, No. 3-4, pp. 33-41.

Kozorog, Miha 2011. "Pa Tminu se patiepaje": življenjski svet lokalne skupnosti mladih v uglasbenih besedilih. Drugi del: ustvarjanje lokalnosti. ["The Ramble around Tolmin": The Life-World of a Local Youth Community Reflected in Lyrics. Part Two: The Creation of Locality.] Glasnik SED, Vol. 51, No. 1-2, pp. 10-16. Available at https://issuu.com/glasnik_sed/docs/glasnik_sed_-_junij_2011/90, last accessed on 24 July 2018. 
Leydi, Roberto 1963. Il povero soldato 2. Serie "Canti politici e sociali." DS 13. Milan: I dischi del sole. Vinyl (7", EP).

Muršič, Rajko 2000. Trate vaše in naše mladosti: zgodba o mladinskem in rock klubu. [The Lawns of Your and Our Youth: A Tale about Youth and Rock Club.] Ceršak: Subkulturni azil.

Navaro-Yashin, Yael 2012. The Make-Believe Space: Affective Geography in a Postwar Polity. Durham \& London: Duke University Press.

Pivato, Stefano 2007. Bella ciao: Canto e politica nella storia d'Italia. Bari: Editori Laterza.

Saunders, Nicholas J. 2001. Matter and Memory in the Landscapes of Conflict: The Western Front 1914-1999. In: Barbara Bender \& Margot Winer (eds.) Contested Landscapes: Movement, Exile and Place. Oxford: Berg, pp. 37-53.

Tul, Vlasta 2002. "Na Mostu se vse zve, če ne prej pa...”: Komentirana objava zapisnika seje krajevne organizacije Socialistične zveze delovnega ljudstva Most na Soči z dne 15. julija 1953. [“In Most na Soči Everything Gets Out, If Not Before Then...": A Commented Publication of Notes from the Meeting of Local Organization of Socialist Alliance of Working People of Most na Soči from July 15, 1953.] Zbornik Pokrajinskega arhiva v Novi Gorici. Nova Gorica: Pokrajinski arhiv, pp. 132-159. 